\title{
Partial hemipelvectomy: An alternative for improving dogs' life quality
}

\author{
Priscila Inês Ferreira ${ }^{1}$ Guilherme Rech Cassanego ${ }^{2}$ (D) Paula Cristina Basso ${ }^{3}$ \\ Daniel Curvello de Mendonça Müller ${ }^{*}$ (D)
}

${ }^{1}$ Graduação em Medicina Veterinária, Universidade Federal de Santa Maria (UFSM), Santa Maria, RS, Brasil.

${ }^{2}$ Programa de Pós-graduação em Medicina Veterinária, Universidade Federal de Santa Maria (UFSM), Santa Maria, RS, Brasil.

${ }^{3}$ Hospital Veterinário Universitário, Universidade Federal de Santa Maria (UFSM), Santa Maria, RS, Brasil.

${ }^{4}$ Departamento de Clínica de Pequenos Animais, Universidade Federal de Santa Maria (UFSM), 97105-900, Santa Maria, RS, Brasil. E-mail: mullerdcm@gmail.com. "Corresponding author.

\begin{abstract}
Partial hemipelvectomy refers to the surgical removal of a pelvic segment, which is performed for pelvic bone neoplasms, severe fractures, or poor bone union. This study presents the cases of seven dogs, six of which have neoplasms involving the hip joint and one with severe pelvic canal narrowing due to a poorly consolidated trauma. Partial caudal hemipelvectomy was performed for all the dogs to improve the quality of life and delay euthanasia. Of the seven cases, six required the use of a polypropylene mesh for the pelvic wall closure, with $85.71 \%$ of them acquiring manageable complications in the postoperative period. Despite these complications, an overall improvement in the quality of life was reported to be significant in the operated animals due to the removal of the cause of pain or discomfort. Thus, it was concluded that partial hemipelvectomyis beneficial for dogs with pelvic conditions. Furthermore, the main complication due to the lack of a pelvic wall for primary occlusion was circumvented by using a polypropylene mesh, showing that possible complications in this procedure can be appropriately managed.
\end{abstract}

Key words: chondrosarcoma, osteosarcoma, lipoma, complications.

Hemipelvectomia parcial: alternativa para melhoria na qualidade de vida em cães

RESUMO: A hemipelvectomia parcial consiste na remoção de segmento pélvico, indicada para neoplasmas com envolvimento de ossos da pelve, fraturas graves ou má união óssea. Esse trabalho apresenta sete pacientes caninos, dos quais seis portadores de neoplasmas envolvendo a articulação coxofemoral e um com grave estreitamento do canal pélvico, resultado de traumatismo mal consolidado. Com o intuito de fornecer qualidade de vida aos cães e postergar a eutanásia, todos foram operados pela técnica de hemipelvectomia parcial média a caudal. Dos sete pacientes, seis necessitaram do uso de tela de polipropileno para fechamento da parede pélvica e apresentaram $85,71 \%$ de complicações manejáveis no pós-operatório. No entanto, a melhora na qualidade de vida dos animais operados foi significativa, tendo sido removida a causa da dor ou desconforto desencadeado pela alteração anatomica local. Conclui-se que a técnica é benéfica aos pacientes, tendo como principal complicação, a falta de parede pélvica para oclusão primária, contornada com uso de tela de polipropileno pelos autores.

Palavras-chave: condrossarcoma, osteossarcoma, lipoma, complicações.

\section{INTRODUCTION}

Hemipelvectomy is defined as the surgical resection of a pelvic segment, which is indicated in the treatment of neoplasms involving the acetabulum and surrounding tissues, severe fractures, or in poor pelvic bone union (KRAMER et al., 2008). Notably, this treatment becomes challenging in primary tumors involving the pelvic region due to the invasive and traumatic approach needed for complete tumor cell excision (BARBUR et al., 2015).
In dogs, the most frequent primary bone neoplasm is osteosarcoma, comprising $85 \%$ of diagnosed neoplasms originating from the skeleton, and is followed by chondrosarcoma, fibrosarcoma, hemangiosarcoma, giant cell tumor, liposarcoma, lymphoma, osteoma, and multiple myeloma (DALECK et al., 2006). Among these, osteosarcoma, chondrosarcoma, fibrosarcoma, and hemangiosarcoma are the most frequent malignant bone neoplasms requiring aggressive and comprehensive procedures (SCHULZ, 2014; BENATTO et al., 2019). 
There are four main surgical techniques for hemipelvectomy:(1) total hemipelvectomy, which includes the limb and hemipelvis from the pubic symphysis to the sacroiliac junction; (2) medium to cranial partial hemipelvectomy, which includes the limb and hemipelvis in the cranial portion of the acetabulum;(3) mid-to-caudal partial hemipelvectomy, which includes the limb and hemipelvis in a portion of the pubic symphysis or a portion of the ischium to the middle ilium; and (4) partial caudal hemipelvectomy, which includes the caudal portion of the ischium and pubis, with preservation of the acetabulum and limb. It should be noted that before performing these techniques, each patient requires specific evaluation and planning, which can vary depending on the surgical technique used (KRAMER et al., 2008).

In this study, we present seven canine cases, including six with neoplasms involving the hip joint and one with severe pelvic canal narrowing due to a poorly consolidated trauma. In order to improve their quality of life and delay euthanasia, all cases were operated using the mid-to-caudal partial hemipelvectomy technique. The study demonstrated the successful application of this technique, as well as discussing the main complications observed following its execution.

\section{MATERIALS AND METHODS}

Seven dogs (three males and four females) that were aged1-12 years and weighed 1.5-33 $\mathrm{kg}$ were included in this study. These dogs were a dachshund, dalmatian, poodle, Australian cattle dog breeds, ormongrels. Afterwards, each dog was assigned an abbreviation (N1-N7), based on the order of service (Table 1). Surgeries were then performed

Table 1 - Main clinical surgical information on the seven cases presented in this study. Attention is drawn to the longevity of the chondrosarcoma cases, as well as their information on post-operative quality of life.

\begin{tabular}{|c|c|c|c|c|c|c|c|}
\hline Patient & N1 & $\mathrm{N} 2$ & N3 & N4 & N5 & N6 & $\mathrm{N} 7$ \\
\hline Breed & $\mathrm{MB}^{*}$ & MB & Dachshund & Dalmatian & Poodle & $\begin{array}{l}\text { Australian } \\
\text { Cattle } \\
\text { Dog }\end{array}$ & MB \\
\hline $\begin{array}{l}\text { Age At } \\
\text { Diagnosis }\end{array}$ & 5 years & 12 years & 7 years & 10 years & 7 years & 3 years & 1 year \\
\hline Diagnosis & Chondrosarcoma & Osteosarcoma & Osteosarcoma & Osteosarcoma & Osteosarcoma & $\begin{array}{l}\text { Infiltrative } \\
\text { Lipoma }\end{array}$ & Trauma \\
\hline $\begin{array}{l}\text { Historic } \\
\text { and } \\
\text { Clinical Signs }\end{array}$ & $\begin{array}{l}\text { Sharp volume } \\
\text { increase in } \\
\text { LHL }^{* *} . \\
\text { Dysuria and } \\
\text { constipation }\end{array}$ & $\begin{array}{c}\text { Pain, } \\
\text { lameness, } \\
\text { skin lesion in } \\
\text { LHL }\end{array}$ & $\begin{array}{l}\text { Intense pain, } \\
\text { lameness } \\
\text { within } 30 \\
\text { days of the } \\
\text { consultation } \\
\text { and edema }\end{array}$ & $\begin{array}{l}\text { Pain, lameness, } \\
\text { continuity } \\
\text { solution, and } \\
\text { myiasis in LHL. } \\
\text { Evolution in } 4 \\
\text { months to } \\
\text { increase bone } \\
\text { volume }\end{array}$ & $\begin{array}{c}\text { Pain, } \\
\text { lameness and } \\
\text { after } 15 \text { days } \\
\text { it evolved to } \\
\text { non-support } \\
\text { of the } \\
\text { affected limb }\end{array}$ & $\begin{array}{l}\text { Volume } \\
\text { increase } \\
\text { in LHL in } \\
\text { the } \\
\text { previous } \\
12 \text { months }\end{array}$ & $\begin{array}{l}\text { Pelvic canal } \\
\text { narrowing, } \\
\text { constipation, } \\
\text { femoral } \\
\text { malunion for } \\
6 \text { months }\end{array}$ \\
\hline $\begin{array}{l}\text { Survival After } \\
\text { Surgery }\end{array}$ & $\begin{array}{l}\text { Alive (3995 } \\
\text { days) }\end{array}$ & 90 days & 62 days & Zero & 91 days & $\begin{array}{c}\text { Alive } \\
\text { (214 days) }\end{array}$ & $\begin{array}{c}\text { Alive (92 } \\
\text { days) }\end{array}$ \\
\hline $\begin{array}{l}\text { Quality of } \\
\text { Life After } \\
\text { Surgery }\end{array}$ & $\begin{array}{l}\text { Life without } \\
\text { restriction }\end{array}$ & $\begin{array}{l}\text { Good at } \\
\text { PO }^{* * *} \text {. Some } \\
\text { episodes of } \\
\text { apathy and } \\
\text { anorexia }\end{array}$ & $\begin{array}{l}\text { Good in PO. } \\
\text { At } 52 \text { days, } \\
\text { apathy and } \\
\text { debilitation. } \\
\text { absence of } \\
\text { pain }\end{array}$ & - & $\begin{array}{l}\text { Apathy in the } \\
\text { PO. Good } \\
\text { recovery until } \\
\text { metastases } \\
\text { appear }\end{array}$ & $\begin{array}{c}\text { Life } \\
\text { without } \\
\text { restriction }\end{array}$ & $\begin{array}{l}\text { life without } \\
\text { restriction }\end{array}$ \\
\hline $\begin{array}{l}\text { Cause of } \\
\text { Death }\end{array}$ & - & $\begin{array}{l}\text { Pulmonary } \\
\text { Metastasis }\end{array}$ & $\begin{array}{l}\text { Metastasis } \\
\text { Pulmonary }\end{array}$ & $\begin{array}{l}\text { He died at the } \\
\text { end of the } \\
\text { surgery }\end{array}$ & Sudden death & - & - \\
\hline $\begin{array}{l}\text { Trans and } \\
\text { Post-operative } \\
\text { Complications }\end{array}$ & $\begin{array}{l}\text { Mesh reaction } \\
\text { after } 9 \text { years of } \\
\text { surgery }\end{array}$ & $\begin{array}{l}\text { Seroma } \\
\text { formation at } \\
\text { PO day } 7\end{array}$ & $\begin{array}{c}\text { Skin suture } \\
\text { dehiscence by } \\
\text { licking at PO } \\
\text { day } 5\end{array}$ & $\begin{array}{l}\text { Immediate PO } \\
\text { cardiorespiratory } \\
\text { brain arrest. }\end{array}$ & $\begin{array}{l}\text { Severe } \\
\text { anemia, } \\
\text { received } \\
\text { blood } \\
\text { transfusion. }\end{array}$ & $\begin{array}{c}\text { Mesh } \\
\text { reaction } \\
\text { after } 161 \\
\text { days of } \\
\text { surgery }\end{array}$ & $\begin{array}{l}\text { Intraoperative } \\
\text { rectum } \\
\text { perforation }\end{array}$ \\
\hline
\end{tabular}

${ }^{*} \mathrm{MB}$ - mixed-breed; ${ }^{* *} \mathrm{LHL}$ - left hind limb; ${ }^{* * *} \mathrm{PO}$ - postoperative period. 
between March 2017 and January 2020, with only one being performed in 2009, allowing for a prospective evaluation for a period of11 years.

Clinical symptoms included increased limb volume, pain on palpation and lameness, or limbun supported on the ground. In this study, only one case had no pain or lameness; however,it had a one-year history of volume increase from the digits to the back. Another case had a history of previous trauma, absence of femur consolidation with consequent poor pelvic union, presence of fecaloma, and difficulty in moving and positioning. All dogs underwent radiographic evaluations of both pelvic limbs in order to determine the extensiveness of the changes or involvement of the pelvic area and of the chest, especially in the cases of suspected neoplastic disease (Figure 1). Additionally, none of the six cancer patients showed metastases in the preoperative radiographic assessment.

The six patients with suspected neoplastic disease also underwent fine needle aspiration cytology (FNAC), wherein the cytology result indicated the number of healthy bone edges that required excision. Following limb amputation, these dogs were referred for histopathological analysis.

The surgical technique in this study followed the same pattern for all seven animals but with slight variations. Once positioned in lateral decubitus with the affected pelvic limb facing upwards, a circular skin incision was made in the proximal femoral region. The loose subcutaneous tissue was then dissected until an area free of tumor mass was identified. After sectioning the muscles, hemostasis was achieved via ligation using multifilament synthetic absorbable yarn (Polyglactin 910, Shalon ${ }^{\circledR}$ Suturas, GO, Brazil), with caliber variation depending on the vessel diameter. The three osteotomy sites considered in this technique were the proximal ilium body, ischial symphysis, and pubic body. Moreover, a manual bone saw was used in three cases, whereas an oscillating bone saw was used for sectioning in the remaining four due to its availability. Therefore, the procedures performed in this study were classified as mid-to-caudal partial hemipelvectomies (Figure 2).

As expected, following limb removal, there was no pelvic wall to contain the viscera, such as the rectum and uterus, except for one case which did not require complete excision, since the cause was traumatic. A polypropylene surgical mesh (Shalon ${ }^{\circledR}$ Suturas, GO, Brazil) was implanted in these six dogs to correct this defect. Each mesh was fixed using non-absorbable synthetic monofilament sutures
(Nylon, Shalon ${ }^{\circledR}$ Suturas, GO, Brazil) in the three remaining bone ends after perforations were created using $1.5-\mathrm{mm}$ pins, and there maining was fixed on the adjacent muscles using the same type of thread in an isolated pattern. More specifically, the muscles were synthetized and subcutaneous tissues were reduced with multifilament synthetic absorbable sutures

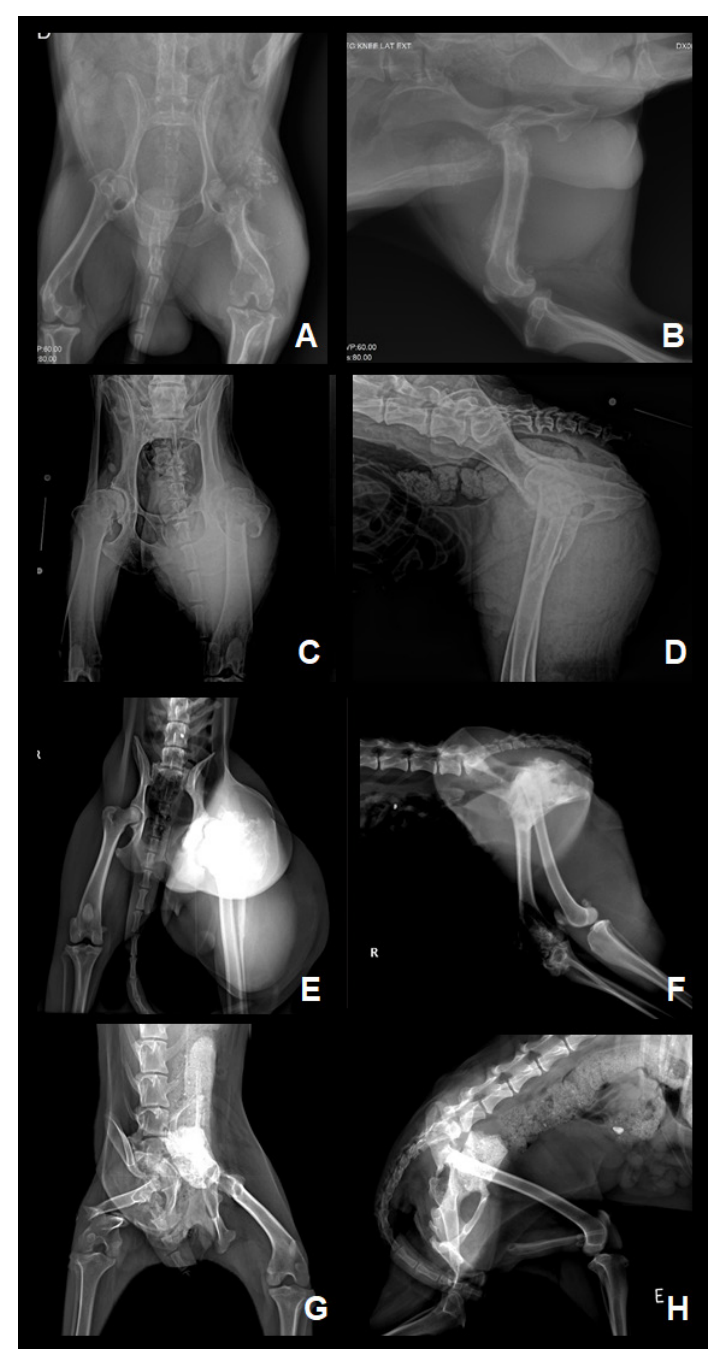

Figure 1 - Radiographic images of four of the seven casesprior to partial hemipelvectomy. Images A and B show the changed left hip joint,which was diagnosed as osteosarcoma, as demonstrated in the patient corresponding to images $\mathrm{C}$ and $\mathrm{D}$. Images $\mathrm{E}$ and $\mathrm{F}$ show the extension of the lesion caused by the infiltrative lymphoma, affecting the LHL and part of the skin. Images $\mathrm{G}$ and Hshow achange in the RHL architecturewith a poorly consolidated pelvis, which was accompanied by severe constipation.

Ciência Rural, v.52, n.5, 2022. 


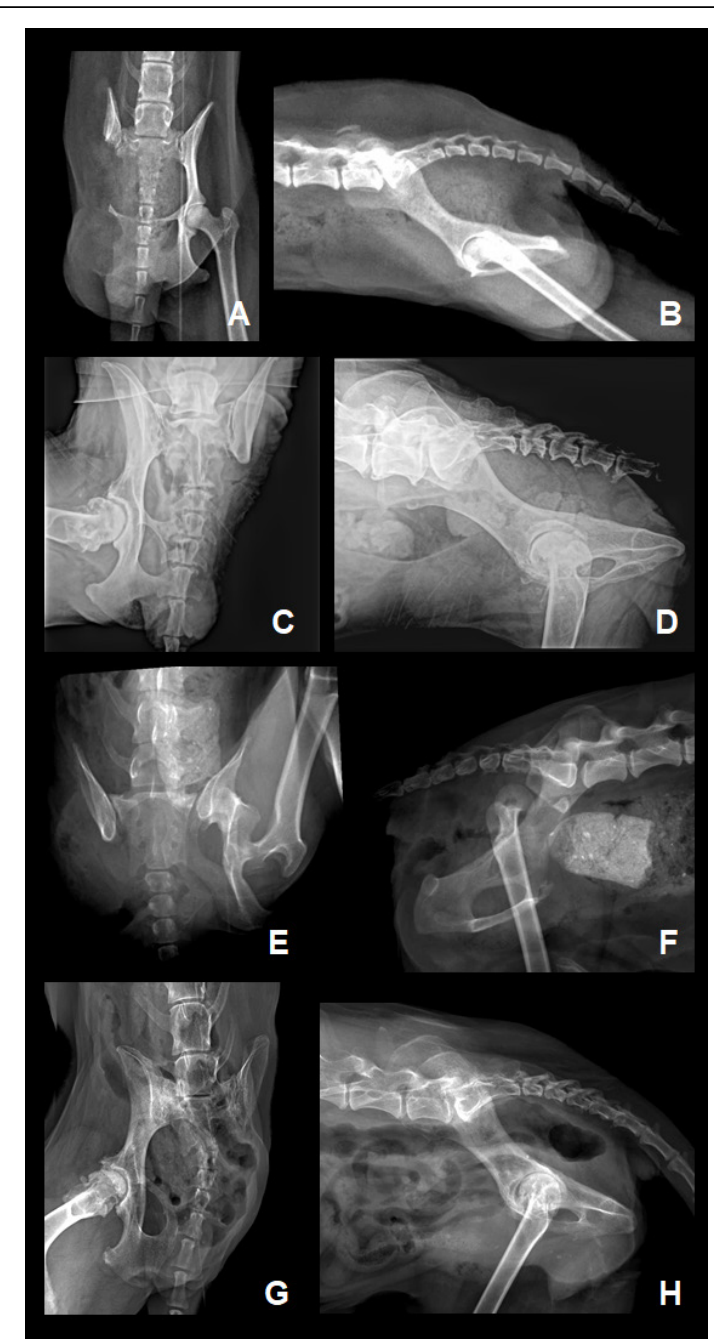

Figure 2 - Images of the four patients after undergoing partial hemipelvectomy. Images A, B, C, and D show the removal of limbs, acetabulum, and part of the body of the ilium of two osteosarcoma cases involving the acetabular region. Images $\mathrm{E}$ and $\mathrm{F}$ show the pelvic canal opening of the case affected by poor consolidation and constipation. Image F specifically shows hip dislocation, which is maintained due to the use of the limb when walking. Images $G$ and $\mathrm{H}$ show the radiographic evaluation of the chondrosarcoma case 11 years after the surgical procedure, as reported by MULLER et al. (2010).

(Polyglactin 910, Shalon ${ }^{\circledR}$ Suturas, GO, Brazil) using a cross mattress suture pattern. Subsequently, dermorrhaphy was performed using monofilament synthetic non absorbable sutures (Nylon, Shalon ${ }^{\circledR}$ Suturas, GO, Brazil) in a simple isolated pattern.

The animals were discharged from the hospital with a prescription of $0.1 \mathrm{mg} \cdot \mathrm{kg}^{-1}$ meloxicam for 3 days, $4 \mathrm{mg} . \mathrm{kg}^{-1}$ tramadol hydrochloride for 5 days, $25 \mathrm{mg} . \mathrm{kg}^{-1}$ sodium dipyrone for 5 days, and $30 \mathrm{mg} \cdot \mathrm{kg}^{-1}$ cephalexin for 7 days. All tutors were instructed to clean the surgical wound with a $0.9 \%$ $\mathrm{NaCl}$ solution twice a day, until the stitches were removed in 10 days.

\section{RESULTS AND DISCUSSION}

As previously mentioned, the six cancer cases underwent FNAC, one case was suspected to be chondrosarcoma, four to be osteosarcoma, and one remained inconclusive. Further histopathological examination confirmed chondrosarcoma (N1), three of the four suspected osteosarcomas (N2, N3 and N5), and diagnosed the inconclusive case as infiltrative lipoma (N6). Histopathological examination was not performed in one case due to the tutor's lack of interest following the patient's death at the end of the surgical procedure (N4), which was most likely due to osteosarcoma. In the last patient (N7), hemipelvectomy was encouraged due to severe pelvic misalignment of traumatic origin, which was not treated after the incident, resulting in marked femoral deviation with incomplete consolidation and intense pelvic canal narrowing, as well as clinical consequences of dyschezia and constipation. Of the seven operated cases, $85.71 \%$ had manageable complications during the postoperative period, which is consistent with BENATTO results (2019), that showed high postoperative complication rates.

The dog with chondrosarcoma was operated in 2009as reported by MULLER et al. (2010). She was diagnosed at the age of five, had a history of urinary difficulty due to bladder compression caused by the presence of amass. Following hemipelvectomy, she was noted to have a good clinical recovery, with monthly evaluations for 7 months not showing tumor recurrence.

Over the years, she had small episodes of sinus formation, which were treated with antibiotic therapy. Nine years following the surgical procedure, we decided to intervene by removing the polypropylene mesh and performing a culture and antimicrobial sensitivity test for her antibiotics. Currently, 11 years after surgery, the patient lives without any signs of infection or difficulty in walking. Moreover, her radiographic examination (Figures $2 \mathrm{G}$ and $2 \mathrm{H}$ ) showed hip joint changes, which were compatible with degenerative joint disease, and thus continuous chondroprotectionuse was introduced in her treatment. Compared to other conditions, hemipelvectomy is highly effective in cases of 
chondrosarcoma with pelvic involvement, because unlike osteosarcoma, amputation of the affected limb alone is already considered effective. However, the dog's average survival following hemipelvectomy was 979 days (FILGUEIRA et al., 2016), thus clearly showing the patient's treatment success (3995 days). Furthermore, the option for hemipelvectomy was based on the severe acetabular bone destruction of this case.

The four patients were suggestive of osteosarcoma hadlimb involvement reaching the pelvic region (Figures 1A, 1B, 1C and 1D), with evident signs of pain; consequently preventing, the dogs from supporting their limb on the ground. Postoperatively, one of the animals required blood transfusion due to blood loss during the transoperative period. In another case, seroma was formed, which was drained and treated with cephalexin $30 \mathrm{mg}$. $\mathrm{kg}^{-1}$ for 10days. Of these cases, Dog N4 had brain cardiopulmonary arrest at the end of surgery and did not respond to resuscitation procedures, resulting in postoperative death.

On the other hand, the three osteosarcoma cases were evaluated after surgery, showing a survival of 62,90 , and 91 days, respectively. Survival in this study was lower when compared to the results reported by BRAY et al. (2014) for28 dogs with osteosarcoma involving the pelvis where the mean survival was 533 days. Another analysis conducted by MORELLO et al. (2011) revealed a survival of 103-175 days after surgery. However, along with chemotherapy, the survival increased to 262-450 days.

Notably, Dogs N2 and N3 (Figures 2A, 2B, 2C and 2D) beganchemotherapy with doxorubicin immediately following post operative recovery,while Dog N5 did not undergo chemotherapy due to tutor's choice, which resulted in a survival of 91 days. Thus, the low survival of dogs in this study compared to that in the study by BRAY et al. (2014) was attributed to the presence of postoperative pulmonary metastases.

More importantly, amputation remains the gold standard in osteosarcoma treatment, as it eliminates the focus of pain, improves the quality of life, and removes the risk of pathological fractures (MORELLO et al., 2011). Furthermore; although, chemotherapy with cisplatin and/or doxorubicin (SCHULZ, 2014) or even carboplatin and lobaplatin used alone or in combination are recommended for appendicular osteosarcomas, it is important to wait for postoperative recovery as there is no advantage in starting chemotherapy immediately after surgery (MORELLO et al, 2011).

On physical examination, Dog N6 had a marked increase limb volume, with a consistency shifting from soft to firm, and a large deformity from the hip joint to the digits (Figures $1 \mathrm{E}$ and $1 \mathrm{~F}$ ); however, he did not feel pain on palpation or lameness. Gait irregularity was also reported to be associated with increased limb weight. Therefore, the decision was made for hemipelvectomy due to severe joint structure impairments and the discomfort of locomotion triggered by the weight of the mass. In the case of a young, three-year-old patient, an improvement in her quality of life was expected following her hemipelvectomy.

The histopathological diagnosis of infiltrative lipoma was also obtained, showing its origin from subcutaneous tissue adipocytes. Infiltrative lipomas are histologically identical to other lipomas, with the exception of their invasive character. For such cases, surgical treatment is commonly effective and results in greater patient survival (SANTOS et al., 2013). According to BRAY et al. (2014), the average survival in dogs with infiltrative lipomas is 940 days. In this study, the patient was evaluated up to 214 days after surgery, with a complication of polypropylene mesh contamination, which required removal after 161 days. For this purpose, surgical curettage, exhaustive washing, and axial pattern flap creation were performed using the superficial caudal epigastric artery rotating the caudal mammary chain. Wound closure was completed, and the patient responded perfectly to the treatment.

In contrast to the six cases of cancer, Dog N7 had a history of trauma for 6 months without surgical treatment. This resulted in consolidation with severe loss of pelvic architecture, markedpelvic canal narrowing, and non-union of the femur, with consequent angular deviation and impossibility of support. There was also a contralateral hip dislocation, but this was partially supported by the limb on the ground. Hemipelvectomy was used in this case due to the intense difficulty in walking and chronic constipation of the animal.

To widen the narrowed pelvic canal, techniques such as triple pelvic osteotomy, external (concurrent limb amputation), or internal (limb preservation) hemipelvectomy can be used (COSTA et al, 2018). In this case, we chose mid-to-caudal partial hemipelvectomy due to the severe trauma associated with the femur, which differed from the other cases in this study since a polypropylene mesh was not required for pelvic wall closure. As it is not a neoplasm, enough musculature can be saved to occlude the region without the need for an associated synthetic material. However, there were still intra operative complications in this case, as part of the rectum had adhered to the fractured acetabulum. Thus, upon pelvis extraction, the rectum was perforated, and 
feces were exposed, requiring immediate correction. Two days after surgery, extravasation recurred, thus local omentopexy and drain adaptation for washing were used. The patient then remained hospitalized until discharge, and 10 days later, did not have any further complications.

Despite the potentially severe complication, the technique was considered successful as constipation was resolved (Figures $2 \mathrm{E}$ and $2 \mathrm{~F}$ ), allowing the patient to walk normally 4 days after the surgery. Re-assessment 10 days after discharge showed that the animal was active, running, and had a visible improvement in quality of life. Given these outcomes, we chose not to surgically intervene for the contralateral hip dislocation.

In all the six cancer cases, the hernia created after limb removal was resolved with polypropylene mesh implantation, which monofilament characteristic provides lesser risk of infection (LEAL et al., 2012). Of the five patients evaluated during the postoperative period, two showed signs of mesh contamination, requiring removal. Although, it was noted that despite having this complication, the implant allowed pelvic wall closure, and recovering of surrounding structures, leading to a successful treatment in both patients. This can be explained due to the fact that the mesh composition stimulates collagen deposition and incorporation into adjacent tissues, which increases scar resistance (LEAL et al., 2012). It was noteworthy that both dogs are still alive, with one of these patients having the longest longevity among those reported in this study (3995 days so far).

\section{CONCLUSION}

Mid-to-caudal partial hemipelvectomy is a viable and beneficial treatment for dogs who need it. The improvement in the quality of life of the animals presented here was significant, resulting in the elimination of the cause of pain and a solution for pelvic deformities. The main complication seen in most cases is the absence of a pelvic wall, which can be resolved using a polypropylene mesh.

\section{ACKNOWLEDGEMENTS}

To Coordenação de Aperfeiçoamento de Pessoal de Nível Superior (CAPES), Brasil.

\section{BIOETHICS AND BIOSSECURITY COMMITTEE APPROVAL}

The authors of the article entitled "Partial hemipelvectomy:An alternative for improving the quality of life in dogs" declare for due purposes that the data contained herein were collected from the hospital surgical routine, and therefore, no submission to the University's CEUA was made. We declare that we are aware of the content of the resolutions of the National Council for the Control of Animal Experimentation (CONCEA) when involving animals. Thus, the authors assume full responsibility for the data presented and are available for possible inquiries, if required by competent bodies.

\section{DECLARATION OF CONFLICT OF INTEREST}

The authors declare no conflict of interest in the data presented in this work.

\section{AUTHORS' CONTRIBUTIONS}

All authors contributed equally to the conception and writing of the manuscript. All authors critically reviewed the manuscript and approved the final version.

\section{REFERENCES}

BARBUR, L. A.; et al. Description of the anatomy, surgical technique, and outcome of hemipelvectomy in 4 Dogs and 5 Cats. Veterinary Surgery, v.44, p.613-626, 2015. Available from: $<$ https://doi.org/10.1111/vsu.12324>. Accessed: Apr. 15 2020. doi: 10.1111 / vsu. 12324 .

BENATTO, M. T.; et al. Complications and cost analysis of hemipelvectomy for the treatment of pelvic tumors. Acta Ortopédica Brasileira, v.27, n.2, p.104-107, 2019. Available from: $<$ https://doi.org/10.1590/1413-785220192702206721>. Accessed: Apr. 18, 2020. doi: 10.1590/1413-785220192702206721.

BRAY, J. P.; et al. Hemipelvectomy: outcome in 84 dogs and 16 cats. A Veterinary Society of Surgical Oncology Retrospective Study. Veterinary Surgery, v.43, p.27-37, 2014. Available from: $<$ https://doi.org/10.1111/j.1532-950X.2013.12080.x>. Accessed: Mar. 18, 2020. doi: 10.1111/j.1532-950X.2013.12080.x.

COSTA, R. C.; et al. Partial internal hemipelvectomy as rescue therapy in obstipation in four dogs: case report. Arquivo Brasileiro de Medicina Veterinária e Zootecnia, v.70, n.6, p.1703-1708, 2018. Available from: <https://doi.org/10.1590/1678-416210239>. Accessed: Apr. 20, 2020. doi: 10.1590/1678-4162-10239.

DALECK, C. R.; et al. Retrospective study of primary osteosarcoma of the pelvic bones in dogs over a 14-month period. Brazilian Journal of Veterinary Research and Animal Science, São Paulo, v.43, n.1, p.125-131, 2006. Available from: <https://www.revistas. usp.br/bjvras/article/view/26527>. Accessed: Apr. 11, 2020. doi: 10.11606/issn.1678-4456.bjvras.2006.26527.

FILGUEIRA, F. G. F.; et al. Myxoid chondrosarcoma in dog knee with rupture of the cranial cruciate ligament. Brazilian Journal of Veterinary Medicine, v.38, n.3, p.227-230, 2016. Available from: $<$ http://rbmv.org/index.php/BJVM/article/view/94>. Accessed: Mar. 27, 2020.

KRAMER, A.; et al. Hemipelvectomy in dogs and cats: technique overview, variations, and description. Veterinary Surgery, v.37, p.413-419, 2008. Available from: <https://doi.org/10.1111/j.1532- 
950X.2008.00405.x>. Accessed: Mar. 27, 2020. doi: 10.1111 / j.1532-950X.2008.00405.x

LEAL, L. M.; et al. Perineal herniorrhaphy with polypropylene screen in dog-casereport. Revista Científica Eletrônica deMedicina Veterinária, v.9, n.18, 2012. Online. Available from: $<$ http://faef.revista.inf.br/imagens arquivos/arquivos_destaque/UjLufzT2yFH6VeO_2013-6-25-17-28-49. pdf>. Accessed: Mar. 25, 2020.

MORELlO, E.; et al. Biology, diagnosis and treatment of canine appendicular osteosarcoma: Similarities and differences with human osteosarcoma. The Veterinary Journal, v.189, p.268 - 277, 2011. Available from: < https://doi.org/10.1016/j. tvj1.2010.08.014>. Accessed: Apr. 11, 2020. doi: $10.1016 /$ j.tvj1.2010.08.014.
MULLER, D. C. de M.; et al. Hemipelvectomy in the treatment of chondrosarcoma in a dog acetabulum. Ciência Rural, Santa Maria, v.40, n.5, p.1218-1222, 2010. Available from: <https://doi. org/10.1590/S0103-84782010000500036>. Accessed: Mar. 20, 2020. doi: 10.1590/S0103-84782010000500036.

SANTOS, R. P.; et al. Compressive myelopathy due to infiltrative spindle cell lipoma in a dog. Ciência Rural, Santa Maria, v.43, n.5, p.861-864, 2013. Available from: <https://doi.org/10.1590/S010384782013000500017>. Accessed: Mar. 15, 2020. doi: 10.1590/ S0103-84782013000500017

SCHULZ, K. S. Other bone and joint diseases. In: FOSSUM, T. W. Cirurgia de Pequenos Animais. 4 ed. Rio de Janeiro: Elsevier, 2014. p. $1395-1399$. 